\title{
EKSPERIMENTASI METODE STAD DAN TGT TERHADAP PRESTASI BELAJAR MATEMATIKA DITINJAU DARI GAYA BELAJAR
}

\author{
Rizki Nurhana Friantini dan Rahmat Winata \\ STKIP Pamane Talino \\ e-mail: keyheart1315@gmail.com,nata win89@yahoo.com
}

\begin{abstract}
Abstrak
Penelitian ini bertujuan untuk mengetahui: (1) Mana yang memberikan prestasi belajar matematika yang lebih baik, STAD atau TGT. (2) Mana yang memiliki prestasi belajar matematika yang lebih baik, siswa yang memiliki gaya visual, auditorial, atau kinestetik. (3) Pada setiap metode pembelajaran, mana yang memberikan prestasi lebih baik pada setiap gaya belajar. (4) Pada setiap gaya belajar, mana yang memberikan prestasi belajar matematika yang lebih baik, STAD atau TGT. Penelitian ini merupakan penelitian eksperimen semu dengan desain faktorial $2 \times 3$. Populasi penelitian adalah seluruh siswa kelas VIII di SMP Negeri 1 Kuala Behe. Sampel berjumlah 63 siswa. Teknik analisis data adalah ANAVA dua jalan dengan sel-sel yang tidak sama. Hasil penelitian menunjukkan sebagai berikut. (1) Metode TGT memiliki prestasi belajar yang lebih baik daripada metode STAD. (2) Siswa dengan gaya belajar visual, auditorial, dan kinestetik memiliki prestasi belajar yang sama. (3) Pada siswa yang diajar dengan menggunakan STAD dan TGT, siswa dengan gaya belajar visual, auditorial, dan kinestetik memiliki prestasi belajar yang sama. (4) Pada siswa dengan gaya belajar visual, auditorial, dan kinestetik, metode TGT memiliki prestasi belajar yang lebih baik daripada metode STAD.
\end{abstract}

Kata Kunci: TGT, STAD, prestasi belajar, gaya belajar

\begin{abstract}
The purpose of the study is to describe: (1) which one has better effect in learning achievement of mathematics between STAD and TGT. (2) which one has better mathematic learning achievement among the students with visual, auditory, or kinesthetic style. (3) which one of the method gives better performance for each learning style. (4) which onr of the learning style gives better mathematics learning achievement, STAD or TGT. This research was a quasi-experimental study with a $2 \times 3$ factorial design. The population of the study was all eighth grade students in SMPN Kuala Behe 1 with 63 students as the sample. The data analysis technique is two-ways ANAVA with different cells. The study show these following results: (1) TGT method has better effect than the STAD method on students learning achievement. (2) Students with visual, auditory, and kinesthetic learning styles have the same learning achievement. (3) the students who were taught by STAD and TGT with visual, auditory, and kinesthetic learning styles have the same learning achievement. (4) Students with visual, auditory, and kinesthetic learning styles has better learning achievement with TGT method instead of STAD method.
\end{abstract}

Keywords: TGT, STAD, learning achievement, learning style 


\section{PENDAHULUAN}

Pemerataan pendidikan di Indonesia masih menjadi masalah yang belum menemui solusi untuk mengatasinya Seperti daerah di Kalimantan khususnya di pedalaman dan perbatasan, pendidikan masih merupakan hal yang belum dapat dinikmati oleh semua anak. Padahal apabila ingin meningkatkan kualitas sumber daya manusia, diperlukan pendidikan yang berkualitas juga. Tetapi kenyataannya pendidikan di pedalaman dan perbatasan Kalimantan masih jauh dari berkualitas. Seperti kurangnya jumlah guru, banyak guru yang mengajar tidak sesuai dengan bidang ilmu yang diajarkan, gedung sekolah yang tidak layak, kurangnya fasilitas pembelajaran, dan lainnya. Tujuan pendahulu bahwa pendidikan adalah hak semua warga negara di Indonesia sepertinya masih jauh dari harapan.

Banyaknya masalah dan kekurangan pada pembelajaran pastinya mempengaruhi prestasi belajar siswa. Bloom (dalam Suprijono, 2012) menyatakan prestasi belajar merupakan tingkat pemahaman dan penguasaan pengetahuan atau keterampilan terhadap suatu konsep dalam mata pelajaran tertentu. Prestasi belajar siswa di daerah pedalaman dan perbatasan Kalimantan yang masih mempunyai banyak masalah dalam pembelajaran juga terkena imbasnya. Salah satunya bisa diketahui dari prestasi belajar siswa kelas VIII SMP Negeri 1 Kuala Behe yang juga berada di daerah pedalaman dan perbatasan. Prestasi belajar siswa kelas VIII SMP Negeri 1 Kuala Behe pada mata pelajaran matematika masih di bawah KKM. Yaitu untuk KKM sebesar 70, rata-rata prestasi siswa pada mata pelajaran matematika hanya mencapai 61.

Berdasarkan hasil observasi di SMP Negeri 1 Kuala Behe diperoleh bahwa metode yang digunakan guru pada pembelajaran matematika adalah metode pembelajaran klasik yaitu secara ceramah. Metode pembelajaran yang digunakan kurang bervariasi dan berpusat pada guru, sehingga siswa kurang termotivasi dan cenderung pasif dalam pembelajaran matematika. Hal ini membuat siswa menjadi bosan dan tidak tertarik untuk mengikuti pembelajaran. Selain itu kurangnya semangat siswa untuk belajar matematika dikarenakan anggapan bahwa matematika sulit dan memusingkan. Oleh karena itu, prestasi belajar matematika belum mencapai hasil yang maksimal. Beberapa hal tersebut membuat peneliti mencari alternatif solusi untuk mengatasinya.

Pembelajaran inovatif yang dapat diterapkan di kelas adalah metode Student Team Achievement Division yang selanjutnya disebut dengan STAD. Menurut Huda (2012:116) STAD merupakan metode yang melibatkan kompetisi antar kelompok. Siswa dikelompokkan secara beragam berdasarkan kemampuan, gender, ras, dan etnis. Pertama-tama, siswa mempelajari materi bersama dengan teman-teman satu kelompoknya, kemudian mereka diuji secara individual melalui kuis-kuis. Menurut Suprijono (2012) langkah STAD yaitu: membentuk kelompok yang anggotanya 4 orang 
secara heterogen, guru menyajikan pelajaran, guru memberi tugas kepada kelompok untuk dikerjakan, guru memberi kuis/pertanyaan kepada seluruh siswa, memberi evaluasi, dan penutup. Sedangkan metode yang lain yang dapat diterapkan di kelas adalah metode Team Games Tournament yang selanjutnya disebut dengan TGT. Menurut Huda (2012) dalam TGT setiap anggota ditugaskan untuk mempelajari materi terlebih dahulu bersama dengan anggota-anggota yang lain, lalu mereka diuji secara individual melalui game akademik. Nilai yang mereka peroleh dari game ini akan menentukan skor kelompok mereka masing-masing. Menurut Slavin (dalam Rusman, 2012) TGT terdiri dari lima langkah, yaitu tahap penyajian kelas (class precentation), belajar dalam kelompok (teams), permainan (games), pertandingan (tournament), dan penghargaan kelompok (team recognition).

Model pembelajaran kooperatif tipe TGT menghasilkan prestasi belajar yang lebih baik dibandingkan dengan siswa yang dikenakan model pembelajaran konvensional (Putra, 2014). Menurut Purwanti (2013) berdasarkan nilai rata-rata pre tes dan pos tes, metode STAD lebih tinggi daripada TGT sehingga metode STAD menghasilkan prestasi yang lebih baik daripada metode TGT. Menurut Huda (2012) STAD mirip dengan TGT, bedanya jika dalam STAD yang digunakan adalah kuis, maka dalam TGT istilah tersebut biasanya berganti menjadi game akademik. Game akademik yang berupa permainan tentunya sangat diminati leh siswa, sehingga diduga siswa akan lebih menyenangi belajar dengan metode pembelajaran TGT daripada STAD.

Faktor lain mempengaruhi prestasi siswa diantaranya gaya belajar. Putra et al (2014) menyatakan gaya belajar merupakan cara di mana individu memproses dan mengolah informasi dalam situasi belajar. Berdasarkan hal tersebut diduga gaya belajar siswa berpengaruh pada terhadap prestasi belajar siswa. Menurut Nasution (2011) gaya belajar atau learning style adalah cara bereaksi dan menggunakan perangsangperangsang yang diterimanya dalam proses belajar. Gaya belajar dibagi menjadi 3 yaitu gaya belajar visual, auditorial, dan kinestetik. Menurut DePorter dan Hernacki (2012) orang visual belajar melalui apa yang mereka lihat, pelajar auditorial melakukannya melalui apa yang mereka dengar, dan pelajar kinestetik belajar lewat gerak dan sentuhan. Oleh karena itu, diduga pada metode yang menerapkan diskusi dan game pada pembelajarannya, siswa yang memiliki gaya belajar kinestetik dapat lebih aktif dan semangat (Bire, Geradus, \& Bire, 2014).

Penelitian ini mempunyai tujuan untuk mengetahui (1) manakah yang mempunyai prestasi belajar matematika lebih baik antara penerapan metode STAD dengan TGT, (2) manakah yang mempunyai prestasi belajar matematika yang lebih baik antara siswa dengan gaya belajar visual, auditorial, dan kinestetik. (3) pada masing-masing metode pembelajaran, manakah yang memberikan prestasi lebih baik antara siswa yang memiliki 
gaya belajar visual, auditorial, dan kinestetik. (4) pada masing-masing gaya belajar, manakah yang memberikan prestasi belajar matematika lebih baik antara siswa yang menerapkan metode STAD dan TGT.

Hipotesis pada penelitian ini adalah (1) siswa yang menerapkan metode pembelajaran TGT mempunyai prestasi belajar matematika lebih baik dibandingkan siswa yang menerapkan metode pembelajaran STAD. (2) siswa yang memiliki gaya belajar kinestetik mempunyai prestasi belajar matematika lebih baik dari siswa yang memiliki gaya belajar visual dan auditorial, siswa yang memiliki gaya belajar auditorial mempunyai prestasi belajar matematika lebih baik dari siswa yang memiliki gaya belajar visual. (3) pada metode pembelajaran STAD, siswa yang memiliki gaya belajar auditorial mempunyai prestasi belajar matematika yang lebih baik dibandingkan siswa yang memiliki gaya belajar visual dan kinestetik, serta siswa yang memiliki gaya belajar kinestetik mempunyai prestasi belajar matematika yang lebih baik dibandingkan siswa yang memiliki gaya belajar visual. Sedangkan pada metode pembelajaran TGT, siswa yang memiliki gaya belajar kinestetik mempunyai prestasi belajar matematika yang lebih baik dibandingkan siswa yang memiliki gaya belajar visual dan auditorial, serta siswa yang memiliki gaya belajar auditorial mempunyai prestasi belajar matematika yang lebih baik dibandingkan siswa yang memiliki gaya belajar visual. (4) Pada siswa yang memiliki gaya belajar visual, siswa yang menerapkan metode pembelajaran STAD mempunyai prestasi belajar lebih baik daripada metode pembelajaran TGT, serta pada siswa yang memiliki gaya belajar auditorial dan kinestetik, siswa yang menerapkan metode pembelajaran TGT mempunyai prestasi belajar matematika lebih baik dari siswa yang menerapkan metode pembelajaran STAD.

\section{METODE}

Penelitian ini dilaksanakan di SMP Negeri 1 Kuala Behe pada semester satu tahun pelajaran 2018/2019. Jenis penelitian ini adalah penelitian eksperimental semu (quasi experimental research). Populasi dalam penelitian ini adalah semua siswa Kelas VIII SMP Negeri 1 Kuala Behe yang terbagi menjadi 5 kelas. Sampling dalam penelitian menggunakan teknik cluster random sampling, yaitu dari 5 kelas diacak sehingga terpilih sampel kelas VIIIA untuk menerapkan metode STAD dan VIIIB untuk menerapkan metode TGT. Sebelumnya telah dilakukan uji keseimbangan di kelas VIIIA dan VIIIB untuk melihat apakah kelas dalam keadaan seimbang atau tidak.

Metode pengumpulan data penelitian meliputi metode dokumentasi, tes, dan angket. Data prestasi belajar matematika dianalisis menggunakan analisis variansi dua jalan dengan sel tak sama. Sebelumnya dilakukan uji prasyarat meliputi uji normalitas populasi menggunakan metode Kolmogorov-Smirnov dan uji homogenitas variansi populasi menggunakan metode Levene. Uji hipotesis menggunakan analisis variansi dua 
jalan dengan sel tak sama. Apabila hasil analisis variansi menunjukkan bahwa hipotesis nol ditolak, dilakukan uji lanjut pasca anava menggunakan metode Scheffe'. (Budiyono, 2009).

\section{HASIL DAN PEMBAHASAN}

Uji prasyarat analisis telah dilakukan sebelum uji hipotesis yaitu normalitas dan homogenitas. Uji normalitas dan homogenitas dilakukan tehadap nilai ulangan harian materi sebelum materi Pola Bilangan. Setelah dianalisis, ternyata sampel berasal dari populasi berdistribusi normal dan mempunyai variansi yang sama atau homogen. Selanjutnya dilakukan uji keseimbangan dengan menggunakan uji-t. Berikut hasil dari uji keseimbangan.

Tabel 1. Rangkuman Uji Keseimbangan

\begin{tabular}{ccccc}
\hline Hitung & t hitung & df & t tabel & Keputusan \\
\hline Uji Keseimbangan & 0.792 & 61 & 1.96 & Ho diterima \\
\hline
\end{tabular}

Hasil uji prasyarat menyimpulkan bahwa semua sampel berasal dari populasi yang berdistribusi normal dan populasi-populasi mempunyai variansi yang sama. Selanjutnya dilakukan uji hipotesis menggunakan anava dua jalan dengan sel tak sama. Rangkuman anava dua jalan dengan sel tak sama disajikan pada Tabel 2.

Tabel 2. Rangkuman Analisis Variansi Dua Jalan dengan Sel Tidak Sama

\begin{tabular}{ccccc}
\hline Sumber & $\mathrm{dk}$ & $\mathrm{F}_{\text {obs }}$ & $\mathrm{F}_{\alpha}$ & Keputusan Uji \\
\hline Metode Pembelajaran (A) & 1 & 20.21 & 4.04 & $H_{0}$ ditolak \\
Gaya Belajar (B) & 2 & 0.47 & 3.19 & $H_{0}$ diterima \\
Interaksi (AB) & 2 & 1.51 & 3.19 & $H_{0}$ diterima \\
Galat (G) & 57 & - & - & - \\
Total & 62 & - & - & - \\
\hline
\end{tabular}

Berdasarkan Tabel 2, $H_{0 A}$ ditolak berarti model pembelajaran kooperatif tipe STAD dan TGT memberikan efek yang berbeda terhadap prestasi belajar matematika siswa. Hipotesis $H_{0 \mathrm{~B}}$ diterima berarti gaya belajar visual, auditorial, dan kinestetik memberikan efek yang sama terhadap prestasi belajar matematika siswa. Hipotesis $H_{0 A B}$ diterima berarti tidak terdapat interaksi antara model pembelajaran dan gaya belajar siswa terhadap prestasi belajar matematika siswa. Selanjutnya untuk menjawab rumusan masalah dilakukan dari data pada Tabel 3.

Tabel 3. Rerata masing-masing Sel

\begin{tabular}{ccccc}
\hline \multirow{2}{*}{ Metode } & \multicolumn{3}{c}{ Gaya Belajar } & Rerata \\
\cline { 2 - 4 } & Visual & Auditorial & Kinestetik & Marginal \\
STAD & 60.20 & 64.50 & 66.00 & 63.57 \\
TGT & 75.86 & 77.20 & 71.33 & 74.80 \\
Rerata & 68.03 & 70.85 & 68.67 & \\
Marginal & 6.03 & \\
\hline
\end{tabular}


Berdasarkan hasil analisis variansi dua jalan dengan sel tak sama diperoleh bahwa $H_{O A}$ ditolak. Hal ini berarti siswa yang menerapkan metode STAD dan TGT mempunyai prestasi belajar matematika yang berbeda. Tetapi karena variabel metode pembelajaran hanya mempunyai 2 nilai (yaitu STAD dan TGT), maka untuk mengetahui mana metode pembelajaran yang menghasilkan prestasi belajar matematika lebih baik dapat dilihat dari rata-rata marginal prestasi belajar matematika masing-masing metode pembelajaran. Dari tabel 3 di atas dapat diperoleh bahwa rerata marginal metode TGT lebih tinggi daripada rerata marginal metode STAD. Oleh karena itu, dapat disimpulkan bahwa siswa yang menerapkan metode pembelajaran TGT mempunyai prestasi belajar matematika lebih baik dari metode pembelajaran STAD. Hasil ini sesuai dengan hasil penelitian Fadila at al., (2014) yaitu bahwa siswa yang pembelajarannya dengan menggunakan model pembelajaran TGT dengan pendekatan kontekstual memiliki prestasi belajar matematika yang dihasilkan lebih baik daripada siswa yang menggunakan model pembelajaran STAD dengan pendekatan kontekstual.

Berdasarkan analisis variansi dua jalan sel tak sama diperoleh bahwa $H_{0 B}$ diterima. Oleh karena itu dapat disimpulkan bahwa masing-masing jenis gaya belajar memberikan efek yang sama terhadap prestasi belajar matematika, sehingga baik siswa yang memiliki gaya belajar visual, auditorial, dan kinestetik tidak ada yang mempunyai prestasi belajar matematika yang lebih baik. Hal ini sesuai dengan hasil penelitian Rahman dan Ahmar (2017) yang menyatakan bahwa tidak ada efek yang signifikan antara gaya belajar dan prestasi belajar di Kelas 1 SMA N 1 Galesong Selatan. Hasil penelitian berbeda dengan hipotesis dikarenakan baik siswa yang memiliki gaya belajar visual, auditorial, dan kinestetik sangat aktif dalam melaksanakan pembelajaran dengan metode STAD dan TGT.

Analisis variansi dua jalan sel tak sama diperoleh bahwa $H_{0 A B}$ diterima sehingga dapat disimpulkan bahwa tidak ada interaksi antara metode pembelajaran dan gaya belajar terhadap prestasi belajar matematika. Oleh karena tidak terdapat interaksi maka apabila ditinjau perbandingan antar sel pada baris yang sama, maka karakteristik perbedaan masing-masing jenis gaya belajar akan sama pada setiap jenis metode pembelajaran. Dapat dilihat pada Tabel 3, bahwa secara marginal rerata prestasi belajar siswa yang memiliki gaya belajar visual, auditorial, dan kinestetik hampir sama besarnya, sehingga dapat disimpulkan pada masing-masing metode pembelajaran, siswa yang memiliki gaya belajar visual, auditorial, dan kinestetik mempunyai prestasi belajar matematika yang sama baik. Hasil tersebut sama dengan penelitian Murdoko at al., (2017) yaitu siswa dengan masing-masing gaya belajar visual, auditorial, dan kinestetik yang medapat pembelajaran dengan model TAI memperoleh prestasi belajar yang sama dengan siswa yang mendapatkan pembelajaran dengan model TGT. Hasil penelitian berbeda 
dengan hipotesis dikarenakan baik siswa yang memiliki gaya belajar visual, auditorial, dan kinestetik melaksanakan pembelajaran dengan metode STAD ataupun TGT dengan baik dan aktif serta semangat sebab metode yang digunakan berbeda dengan yang biasa siswa terapkan sehingga prestasi belajar yang dihasilkan sama baiknya. Sedangkan apabila ditinjau perbandingan antar sel pada kolom yang sama, karakteristik perbedaan antara metode pembelajaran STAD dan TGT untuk setiap masing-masing jenis gaya belajar sama. Dilihat pada Tabel 3, bahwa secara marginal, siswa yang menerapkan metode pembelajaran TGT mempunyai prestasi belajar matematika lebih baik dari metode pembelajaran STAD, baik pada siswa yang memiliki gaya belajar visual, auditorial, maupun kinestetik. Dapat disimpulkan pada masing-masing gaya belajar, metode pembelajaran TGT memberikan prestasi belajar matematika lebih baik dari metode pembelajara STAD. Hasil penelitian berbeda dengan hipotesis dikarenakan pada metode TGT dengan adanya game akademik siswa lebih semangat belajar dan melaksanakan pembelajaran dibandingkan dengan metode STAD.

\section{SIMPULAN}

Berdasarkan pembahasan di atas dapat disimpulkan bahwa siswa yang menerapkan metode pembelajaran TGT mempunyai prestasi belajar matematika lebih baik dibandingkan metode pembelajaran STAD pada pokok materi pola bilangan siswa kelas VIII SMP Negeri 1 Kuala Behe tahun ajaran 2018/2019. Masing-masing jenis gaya belajar memberikan efek yang sama terhadap prestasi belajar matematika, sehingga baik siswa yang memiliki gaya belajar visual, auditorial, dan kinestetik tidak ada yang mempunyai prestasi belajar matematika yang lebih baik pada pokok materi pola bilangan siswa kelas VIII SMP Negeri 1 Kuala Behe tahun ajaran 2018/2019. Pada metode pembelajaran STAD dan TGT, siswa yang memiliki gaya belajar visual, auditorial, dan kinestetik mempunyai prestasi belajar yang sama pada pokok materi pola bilangan siswa kelas VIII SMP Negeri 1 Kuala Behe tahun ajaran 2018/2019. Pada gaya belajar visual, auditorial, dan kinestetik, siswa yang menerapkan metode pembelajaran TGT mempunyai prestasi belajar matematika yang lebih baik daripada STAD pada pokok materi pola bilangan siswa kelas VIII SMP Negeri 1 Kuala Behe tahun ajaran 2018/2019.

\section{DAFTAR PUSTAKA}

Bire, A. L., Geradus, U., \& Bire, J. (2014). Pengaruh gaya belajar visual, auditorial, dan kinestetik terhadap prestasi belajar siswa. Jurnal Kependidikan: Penelitian Inovasi Pembelajaran, 44(2).

Budiyono. 2009. Statistika untuk Penelitian. Surakarta: Sebelas Maret University Press. 
DePorter, B. \& Hernacki, M. 2012. Quantum Learning. Bandung: Kaifa.

Fadila, A., Budiyono, B., \& Riyadi, R. (2014). Eksperimentasi Model Pembelajaran Kooperatif Tipe Stad Dan Tgt Dengan Pendekatan Kontekstual Terhadap Prestasi Belajar Dan Aspek Afektif Matematika Siswa Ditinjau Dari Kecerdasan Majemuk. Jurnal Pembelajaran Matematika, 2(1).

Huda, M. 2012. Cooperative Learning: Metode, Teknik, Struktur dan Model Penerapan. Yogyakarta: Pustaka Pelajar.

Murdoko, 2017. Penerapan model pembelajaran Team Assisted Individualization (TAI) dan Teams Game Tournaments (TGT) pada materi lingkaran ditinjau dari gaya belajar siswa SMP di Kabupaten Wonogiri. Journal of Mathematics and Mathematics Education, 7(1): 58-69.

Nasution. 2011. Berbagai Pendekatan dalam Proses Belajar \& Mengajar. Jakarta: PT Bumi Aksara.

Purwanti, D. E. 2013. The Comparison between STAD and TGT on students, achievement and motivation: Senior High School. Proceedings from the Global Summit on Education. Kuala Lumpur.

Putra, F. G. 2015. Eksperimentasi Model Pembelajaran Kooperatif Tipe Teams Games Tournament (TGT) Berbantuan Software Cabri 3d di Tinjau dari Kemampuan Koneksi Matematis Siswa. Al-Jabar: Jurnal Pendidikan Matematika, 6(2), 143-154.

Rahman, A., \& Ahmar, A. (2017). Relationship between learning styles and learning achievement in mathematics based on genders.

Rusman. 2012. Model-model Pembelajaran: Mengembangkan Profesionalisme Guru. Jakarta: PT. Raja Grafindo Persada.

Suprijono, Agus. 2012. Cooperative Learning. Surabaya : Pustaka Pelajar. 